\title{
Soil microbial biomass in relation to fine root in Kiteni hill Sal forest of Ilam, eastern Nepal
}

\author{
Krishna Prasad Bhattarai* and Tej Narayan Mandal \\ Department of Botany, Post Graduate Campus, Tribhuvan University, Biratnagar, Nepal \\ *E-mail:krishnaprbhattarai@gmail.com
}

\begin{abstract}
Soil microbial biomass in relation to fine root was studied in Kiteni hill Sal (Shorea robusta) forest of Ilam during summer season. The forest had sandy loam type of soil texture. Organic carbon was higher in 0-15 $\mathrm{cm}$ depth $(2.09 \%)$ than in $15-30 \mathrm{~cm}$ depth $(1.53 \%)$. Total nitrogen of 0 $15 \mathrm{~cm}$ depth was $0.173 \%$ and in $15-30 \mathrm{~cm}$ depth was $0.124 \%$. Soil microbial biomass of carbon of Kiteni hill sal forest was $\left(445.14 \mu \mathrm{g} \mathrm{g}^{-1}\right)$ and microbial biomass of nitrogen was $\left(49.07 \mu \mathrm{g} \mathrm{g}^{-1}\right)$. Fine root biomass of this forest was $2.34 \mathrm{t} \mathrm{ha}^{-1}\left(<2 \mathrm{~mm}\right.$ diameter) and $0.93 \mathrm{t} \mathrm{ha}^{-1}$ (2-5 mm diameter) in $0-15 \mathrm{~cm}$ depth and $0.73 \mathrm{t} \mathrm{ha}^{-1}(<2 \mathrm{~mm}$ diameter) and $0.46 \mathrm{t} \mathrm{ha}^{-1}$ (2-5 mm diameter) in $15-30 \mathrm{~cm}$ depth. Organic carbon, total nitrogen, soil microbial biomass carbon and nitrogen of upper layer soil were negatively correlated with fine root biomass of forest.
\end{abstract}

Key words: Hill sal forest, physico-chemical properties, microbial biomass, fine root biomass, Ilam

\section{Introduction}

Hill sal (Shorea robusta Gaertn. f.) forest is an important vegetation of upper tropical belt. It ranges from 300 to $1000 \mathrm{~m}$ altitude in the hilly region and extends from east to west of Nepal (Anonymous, 2002). Forests are the essential and most precious renewable natural resource which plays a key role in the lives of people living both in mountains and lowland areas by supplying fresh water and oxygen as well as repositories of terrestrial biological diversities (Kala, 2004). In the present day, this resource is in danger due to adverse abiotic and biotic stresses resulting from population explosion, industrial development, agriculture and global warming (Bawa \& Dayanandan, 1998). Biodiversity and sources of nutrients decline day to day with increasing human activity in and around forest ecosystem. The vegetation in turn influences the physical and chemical properties of soil to a great extent. This improves the soil structure, infiltration rate and water holding capacity. Soil properties of forest also depend upon topography, climate, vegetation cover, decomposition of litter, turnover rate of fine root and microbial activity.

Soil microbial biomass, which can be either a source or sink of available nutrients, plays a critical role in nutrient transformation in terrestrial ecosystems (Singh et al., 1989). It is an active fraction of soil organic matter and any change in the soil microbial biomass may affect soil organic matter turnover. Diversity in forest types influence soil microbial biomass and activities by determining the quantity and quality of organic matter inputs. Besides forest types, seasonal variations of temperature, rainfall, plant development, and organic matter accumulation from litter fall also have great influences on soil microbial biomass (Chen et al., 2005). Microbial activity and microbial biomass of forest soils are strongly 
related to such soil chemical parameters as $\mathrm{pH}$, cation exchange capacity, and nutrient availability.

The fine roots increase the surface area for growth and multiplication of soil microorganisms, which are key components in nutrient cycling. Belowground carbon input through fine root production and turnover and associated microbial activity are welldocumented processes in the carbon and nutrient cycling of forest ecosystems (Keyes \& Grier, 1981). Fine roots ( $<2 \mathrm{~mm}$ in diameter) are important nutrient sources and sinks, and play important roles in water and nutrient uptake in terrestrial ecosystems. Fine root biomass represents less than $2 \%$ of total ecosystem biomass, whereas fine root production may account for up to $30-75 \%$ of total net primary production. It is estimated that production of fine roots accounts for as much as $33 \%$ of global annual net primary productivity (Jackson et al., 1997). Fine root mortality contribute 18 to $58 \%$ total $\mathrm{N}$ to forest soil, higher than $\mathrm{N}$ addition from aboveground litter fall in some ecosystem (Vogt et al., 1986). The main objective of this study was to analyze the physiochemical properties of soil along with microbial biomass and fine root biomass of hill sal forest and identify the correlation in between microbial biomass on fine root biomass..

\section{Materials and Methods}

Study area

Kiteni Hill sal forest is located in Kolbung of Ilam at an altitude of 850 msl near Kanyam tea state. It lies in between $88^{\circ} 04^{\prime} 02.0^{\prime \prime} \mathrm{E}$ longitude and $26^{\circ} 47^{\prime} 26.6^{\prime \prime} \mathrm{N}$ latitude. The forest is spreaded from Biring Khola on west to Bhalujhodha Khola on the east and Barnedandagaun on south to Kiteni on the north. Kiteni is the highest point of sal forest of Ilam.

\section{Climate}

The climate is subtropical monsoon type. The year is divisible in to three seasons e.g. summer, rainy and winter. The mean monthly minimum temperature is $15.31^{\circ} \mathrm{C}$ and mean monthly maximum temperature is $24.92^{\circ} \mathrm{C}$. The annual rainfall average $1801.76 \mathrm{~mm}$.

\section{Soil and vegetation}

The texture of soil in forest area is sandy loam. Kiteni forest is a dense deciduous vegetation and one of the most significant and complex ecosystem of eastern part of Nepal. It is a Sal (Shorea robusta Gaertn.) dominated mixed upper tropical forest. The other main associates are Schima wallichii, Duabanga grandiflora, Michelia champaca, Madhuca longifolia, Meliosma simplisifolia, Careya arborea, Lagerstroemia parviflora, Dillenia pentagyna, Phyllanthus emblica, Semecarpous anacardium, Casia fistula, Dalbergia latifolia, Sizygium cuminii, Cycas pectinata, Cyathia spinulosa etc.

\section{Soil and fine root sampling}

The study was carried out in hill sal forest of Kiteni during summer season (May, 2012). Soil and fine root samples were collected from thirty random locations on the natural sites from the different depths $0-15 \mathrm{~cm}$ and $15-30 \mathrm{~cm}$. At each location soil was collected from three pits, composited and pulled as one replicate. After carefully removing fine roots and organic materials the air dried samples were sieved through a $2 \mathrm{~mm}$ mesh screen and used for chemical analysis. Fine root $(<5 \mathrm{~mm}$ diameter $)$ biomass was determined from soil monoliths $\left(10 \times 10 \times 30 \mathrm{~cm}^{3}\right)$ on each location in summer season. Soil monoliths were washed 
over a sieve with fine jet of water to retrieve the fine roots which was oven dried at $80^{\circ} \mathrm{C}$ and fine root biomass was calculated.

\section{Physicochemical analysis}

The water holding capacity (WHC) and texture of soil was determined as the methods described by (Piper, 1966). Soil $\mathrm{pH}$ (1:2.5 ratio of soil: water) was measured with digital $\mathrm{pH}$ meter. Soil organic carbon (SOC) was determined by partial oxidation method (Walkley \& Black, 1934). Total nitrogen(TN) content of soil was determined using the micro-Kjeldal methods (Jackson, 1958).Soil microbial biomass C (MB-C) and soil microbial N (MB-N) were determined by chloroform- fumigation method following Vance et al. (1987) and Brookes et al. (1985).

\section{Results}

Soil physico-chemical properties Kiteni sal forest of Ilam such as $\mathrm{pH}$, soil texture, water holding capacity, organic carbon, total nitrogen, soil microbial biomass carbon(MB-C) and nitrogen (MB-N) and fine root biomass have been studied and results are presented in table 1,2 and 3. The PH value was 6.43 in $0-15 \mathrm{~cm}$ and 6.58 in $15-30 \mathrm{~cm}$ soil depth. The WHC value was higher in $0-15 \mathrm{~cm}$ soil depth $(58.41 \%)$ than $15-30 \mathrm{~cm}$ soil depth $(52.51 \%)$. Organic carbon was also higher in $0-15 \mathrm{~cm}$ depth $(2.09 \%)$ than in $15-30 \mathrm{~cm}$ depth $(1.53 \%)$. Total nitrogen of $0-15 \mathrm{~cm}$ depth was $0.173 \%$ and in $15-30 \mathrm{~cm}$ depth was $0.124 \%$. The C:N ratio of $0-15 \mathrm{~cm}$ depth was 12.08 and $15-30 \mathrm{~cm}$ was 12.33 (Tab. 1).

Table 1. Physiochemical properties (mean \pm SE) of soil in Kiteni sal forest of eastern Nepal.

\begin{tabular}{lcc}
\hline Parameters & $\mathbf{0 - 1 5} \mathbf{~ c m}$ & $\mathbf{1 5 - 3 0} \mathbf{~ c m}$ \\
\hline Soil texture & & \\
Sand \% & $65.77 \pm 0.77$ & $68.13 \pm 0.60$ \\
Silt \% & $25.93 \pm 0.86$ & $21.8 \pm 0.76$ \\
Clay \% & $10.73 \pm 0.63$ & $11.00 \pm 0.44$ \\
Textural class & Sandy loam & Sandy loam \\
PH & $6.43 \pm 0.04$ & $6.58 \pm 0.03$ \\
WHC (\%) & $58.41 \pm 1.54$ & $52.51 \pm 1.44$ \\
Organic C (\%) & $2.09 \pm 0.12$ & $1.53 \pm 0.11$ \\
Total nitrogen (\%) & $0.173 \pm 0.005$ & $0.124 \pm 0.004$ \\
C:N ratio & 12.08 & 12.33 \\
\hline
\end{tabular}

Soil microbial biomass carbon of hill sal forest was $\left(445.14 \mu \mathrm{g} \mathrm{g}^{-1}\right)$ and microbial biomass of nitrogen was (49.07 $\mu \mathrm{g} \mathrm{g}^{-1}$. MB-C: MB-N ratio was 9.07 in this forest (Tab. 2)

Table 2. Microbial biomass of carbon and nitrogen $\left(\mu \mathrm{g} \mathrm{g}^{-1}\right)$ (mean \pm SE) 0-15 cm depth of summer season of Kiteni sal forest of eastern Nepal.

\begin{tabular}{lc}
\hline Parameters & Kiteni sal forest \\
\hline Microbial biomass carbon (MB-C) & $445.14 \pm 23.65$ \\
Microbial biomass nitrogen (MB-N) & $49.07 \pm 2.28$ \\
MB-C:MB-N & 9.07 \\
MB-C as \% of organic carbon & 2.13 \\
MB-N as \% of total nitrogen & 2.84 \\
\hline
\end{tabular}


Fine root biomass of kiteni sal forest was $2.34 \mathrm{t} \mathrm{ha}^{-1}(<2 \mathrm{~mm}$ diameter $)$ and $0.93 \mathrm{tha}^{-1}(2-5$ $\mathrm{mm}$ diameter) in $0-15 \mathrm{~cm}$ depth and $0.73 \mathrm{t} \mathrm{ha}^{-1}(<2 \mathrm{~mm}$ diameter $)$ and $0.46 \mathrm{t} \mathrm{ha}^{-1}(2-5 \mathrm{~mm}$ diameter) in $15-30 \mathrm{~cm}$ depth. Total fine root biomass was higher $\left(3.21 \mathrm{t} \mathrm{ha}^{-1}\right)$ in $0-15 \mathrm{~cm}$ depth than 15-30 $\mathrm{cm}$ soil depth $\left(1.20 \mathrm{t} \mathrm{ha}^{-1}\right)$.

Table 3. Fine root biomass $\left(\mathrm{t} \mathrm{ha}^{-1} \pm 1 \mathrm{SE}\right)$ of summer season in Kiteni hill sal forest.

\begin{tabular}{lcc}
\hline Fine root & \multicolumn{2}{c}{ soil depth } \\
\cline { 2 - 3 } diameter & $\mathbf{0 - 1 5} \mathbf{~ c m}$ & $\mathbf{1 5 - 3 0} \mathbf{~ c m}$ \\
\hline$<2 \mathrm{~mm}$ & $2.34 \pm 0.14$ & $0.73 \pm 0.07$ \\
$2-5 \mathrm{~mm}$ & $0.93 \pm 0.09$ & $0.46 \pm 0.1$ \\
\hline Total & $3.21 \pm 0.19$ & $1.20 \pm 0.13$ \\
\hline
\end{tabular}

In the upper layer (0-15m depth) Soil organic carbon, total nitrogen, soil microbial biomass carbon and nitrogen were negatively correlated with fine root biomass of kiteni sal forest of Ilam (Figs. 1, 2, 3, 4).

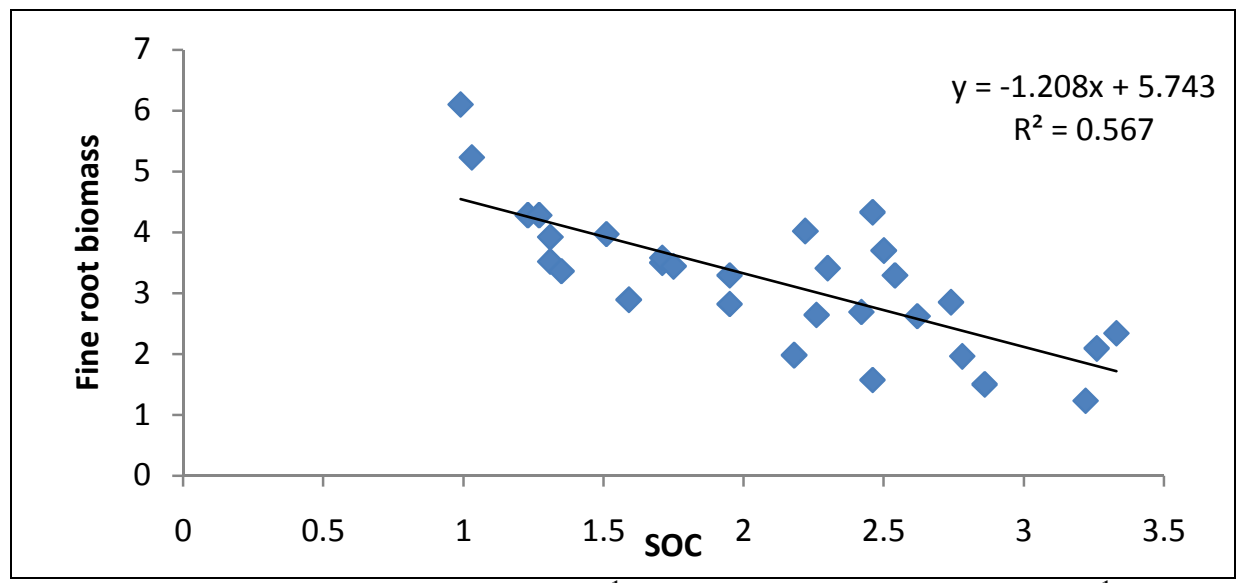

Figure 1. Soil organic carbon $\left(\mu \mathrm{g} \mathrm{g}^{-1}\right)$ and fine root biomass $\left(\mathrm{t} \mathrm{ha}^{-1}\right)$ in $0-$ $15 \mathrm{~cm}$ soil depth in Kiteni hill Sal forest.

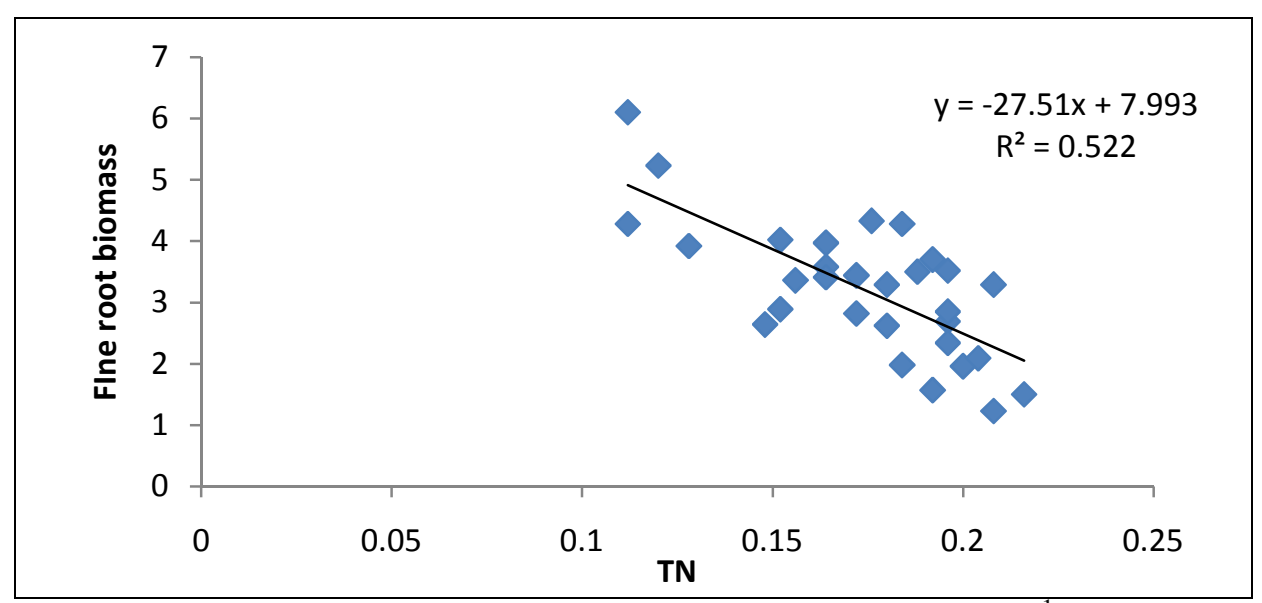

Figure 2. Soil total Nitrogen $(\%)$ and fine root biomass $\left(\mathrm{t} \mathrm{ha}^{-1}\right)$ in $0-15 \mathrm{~cm}$ soil depth in Kiteni hill Sal forest. 


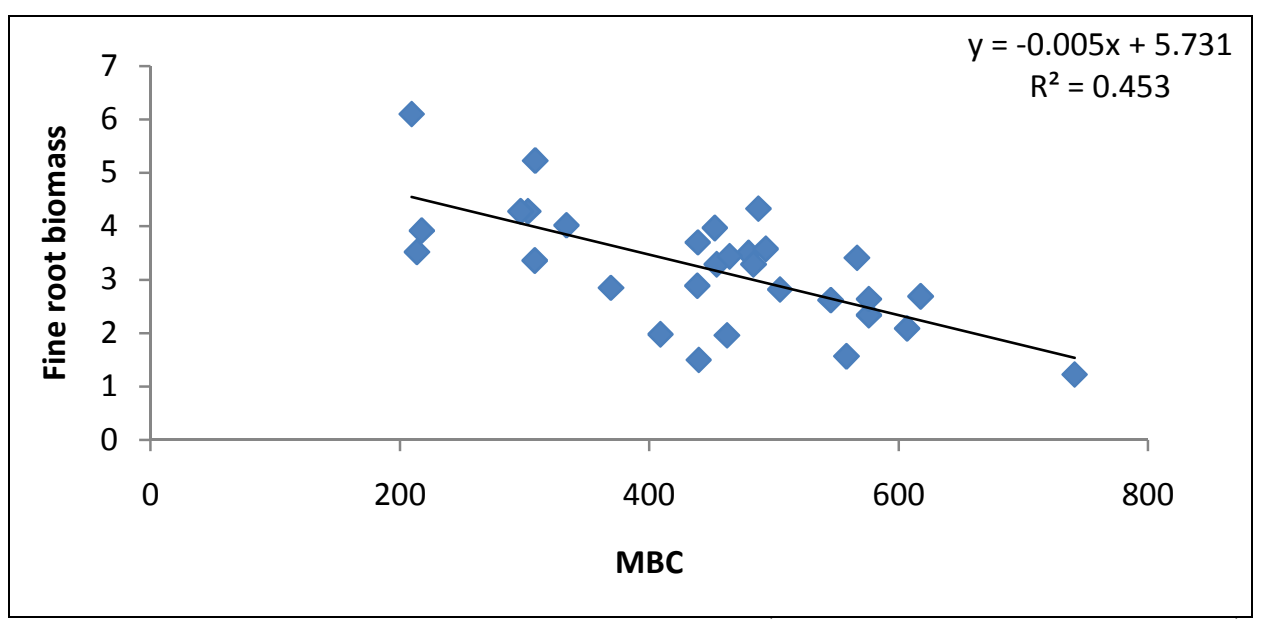

Figure 3. Soil microbial biomass carbon $\left(\mu \mathrm{g} \mathrm{g}^{-1}\right)$ and fine root biomass $\left(\mathrm{t} \mathrm{ha}^{1}\right)$ in $0-15 \mathrm{~cm}$ soil depth in Kiteni hill Sal forest.

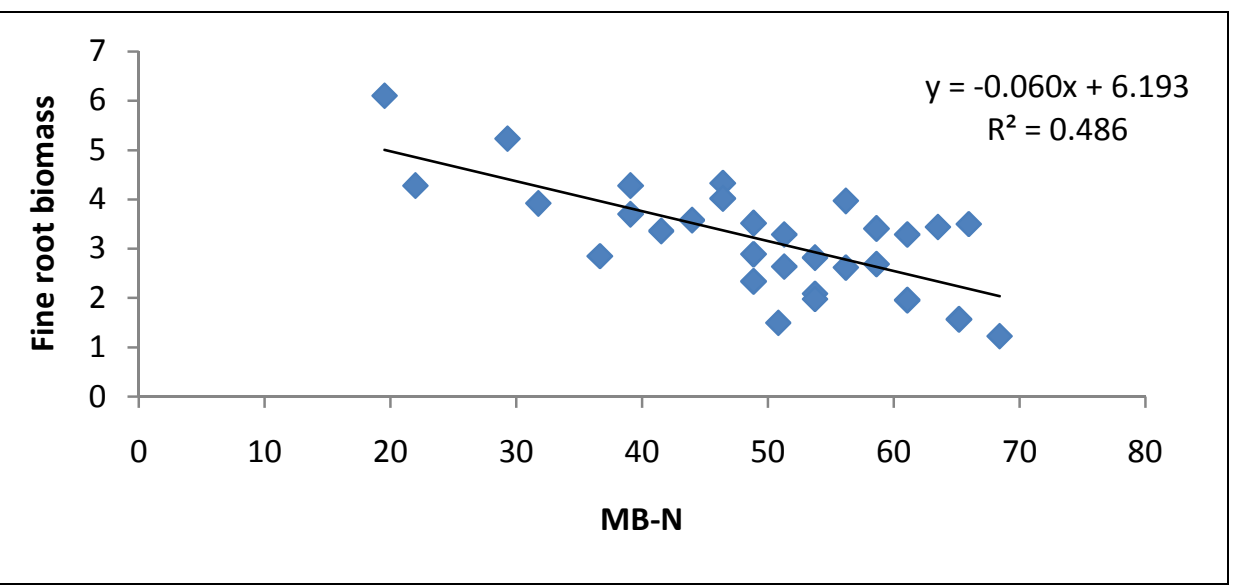

Figure 4. Soil microbial biomass nitrogen $\left(\mu \mathrm{g} \mathrm{g}^{-1}\right)$ and fine root biomass $(\mathrm{t}$ $\left.\mathrm{ra}^{-1}\right)$ in $0-15 \mathrm{~cm}$ soil depth in Kiteni hill Sal forest.

\section{Discussion}

In natural forest, cycling of nutrient is an important feature as considerable amount of nutrients cycle through decomposition of litter, turnover of fine root and microbial activity. Plant tissues (above and below ground litter) are main sources of organic matter which bring about important changes in physical, chemical and biological characteristics of soil and balance the nutrient resources of soils.

In present study the soil $\mathrm{pH}$ in Kiteni sal forest was 6.43 in $0-15 \mathrm{~cm}$ depth and 6.58 in 15-30 $\mathrm{cm}$. In the present study the soil $\mathrm{pH}$ was less acidic then reported by Paudel and Shah (2003) in pure Sal forest. Soil $\mathrm{pH}$ influences the availability of plant nutrients and it is a good indicator of forest fertility (Black, 1968). Water holding capacity was $58.41 \%$ in $0-15 \mathrm{~cm}$ soil depth and 52.51\% in 15-30 cm depth. Paudel and Shah (2003) found that the WHC of mixed Sal forest of Udayapur was $49.80 \%$. This was lower in comparison to WHC of hill Sal forest. WHC of hill sal forest is higher because of dense mat of fine root on upper layer and higher organic carbon of the soil. 
Soil organic carbon of present study was comparable with the value reported by Semwal et al. (2009) who found 2.01-2.38\% of organic carbon in undisturbed forest of Rudraprayag and Pauri Uttarakhand. The total soil nitrogen of Kiteni hill sal forest was comparable with Paudel and Shah (2003) from mixed sal forest (0.11\%) of Udaypur, and the value reported by Juwa (1987) from Nagarkot (0.18-0.28\%) and Sigdel (1994) from Royal Chitwan National Park $(0.13 \%)$. The low nitrogen in hill Sal forest has been due to continuous loses through leaching and run off (Allen, 1964).

Soil microbial biomass may be the main source of nutrients for the plant and may help in nutrient conservation (Singh et al., 1989). Microbial biomass carbon and nitrogen of present study was $445.14 \mu \mathrm{g} \mathrm{g}^{-1}$ and $49.07 \mu \mathrm{g} \mathrm{g}^{-1}$, respectively. Barbhuiya (2006) reported microbial biomass $\mathrm{C}\left(548-1146 \mu \mathrm{g} \mathrm{g}^{-1}\right)$ and the microbial $\mathrm{N}$ values $\left(45.29-92.72 \mu \mathrm{g} \mathrm{g}^{-1}\right)$ in undisturbed forest of Meghalaya. This value was comparatively higher than present study. The microbial biomass $\mathrm{C}$ and microbial $\mathrm{N}$ were lower in the undisturbed site than value (MB-C-778 $\mu \mathrm{g} \mathrm{g}^{-1}$ and MB- N $65 \mu \mathrm{g} \mathrm{g}^{-1}$ ) reported by Mandal (1999) in undisturbed Panchakanya sal forest on plateau of Sunsari district, Nepal. Arunachalam and Arunachalam (2000) reported microbial $\mathrm{C}\left(1522 \mu \mathrm{g} \mathrm{g}^{-1}\right)$ and $\mathrm{N}\left(285 \mu \mathrm{g} \mathrm{g}^{-1}\right)$ of subtropical hill forest at Mawphlang Meghalaya India. Relatively dense growth of plants, greater accumulation of litter and fine root on untouched area favors the growth of microbial population and accumulation of $\mathrm{C}$ and $\mathrm{N}$ in the microbial biomass. MB-C:MB-N ratio was 9.07 in present forest stand. Soil micro flora is a composite of several group of organisms and each microbial group may have a different $\mathrm{C}: \mathrm{N}$ ratio. $\mathrm{C}: \mathrm{N}$ ratio of bacteria is often between 3-5, while in fungi it ranges from 7-15 (Poul \& Clark, 1989). This MB-C: MB-N ratio in hill sal forest may reflect the fungal dominance in the soil microbial biomass.

Fine roots are most significant component contributing to the forest ecosystem. Below ground $\mathrm{C}$ fluxes, indicate that up to $75 \%$ of the annual net primary production can be allocated into fine roots (Gill \& Jackson, 2000). Thus fine roots play a key role in forest ecosystem. Fine root mortality contributes $18-58 \%$ total nitrogen to the forest soil, higher than an addition form above ground litter fall in some ecosystem (Vogt et al., 1986). However due to difficulties in their activities in situ, knowledge of the ecology of fine root is much more limited than above ground components of tree. Fine root biomass production, turn over and nutrients pools have been found to be the result of internal factors as the genotype of plant species and several external factors such as soil properties, stand age and climate (Brassard et al., 2009).

Fine root biomass obtained in present study is comparable with the result of Mc Grodly and Silver (2000) who reported that fine root biomass in the top $10 \mathrm{~cm}$ of soil range from 1.0-5.6 $\mathrm{mg} \mathrm{ha}^{-1}$ along gradient in Luquillo Experimental Forest. Barbhuiya et al. (2012) reported that the fine root biomass was $3505 \mathrm{Kg} \mathrm{ha}^{-1} \mathrm{yr}^{-1}$ in Jeypore Reserve Forest of Assam. Mandal (2011) reported fine root biomass of mature sal forest of Panchakanya, as $4.33 \mathrm{t} \mathrm{ha}^{-1}$ during summer season. This value was lower than present study. Higher fine root biomass may be due to high soil total nitrogen which may cause greater $\mathrm{N}$ up take per unit fine root mass due to increased root predation by soil invertebrates and increased fine root turnover rate resulting in rapid underground carbon cycling (Wang et al., 2012).

Many tropical rain forests develop extensive root mats in the nutrient deficient mineral soil in which they typically occur. Such dense superficial root system aids in nutrient uptake 
from decomposing litter to root. Dense superficial fine root mat in inclined topography of Kiteni hill Sal forest is mainly for soil binding and capturing of nutrients on the soil surface as a result of decomposition of litter and turnover of fine root. Fine root biomass of Kiteni hill Sal forest were negatively correlated with soil organic carbon, total nitrogen, microbial biomass carbon and microbial biomass nitrogen and same result was found by Wang et al. (2012) in the Broad-Leaved Korean Pine Mixed Forest in Northeastern China.

Hence it is concluded that, investigation and assessment of physiochemical properties of soil along with fine root biomass and soil microbial biomass in hill sal forest is an integrated phenomena, which may help in the forest management.

\section{Acknowledgements}

The authors are grateful to the Head, Department of Botany and to the Campus chief of Post Graduate Campus, T.U., Biratnagar, Nepal for providing laboratory and library facilities. The first author is grateful to the Tribhuvan University for Ph.D. study leave and to the University Grants Commission, Nepal for the research fellowship.

\section{References}

Allen, S.E. 1964. Chemical aspects of heather burning. Journal Applied Ecology 1: 347-67.

Anonymous. 2002. Forest and Vegetation Types of Nepal. TISC Document series No. 105. Dept. of forest, Nepal.

Arunachalam, A. \& K. Arunachalam. 2000. Influence of gap size and soil properties on microbial biomass in a subtropical humid forest of North-East India. Plant and soil 223: 185-193.

Barbhuiya, A. 2006. Role of fine roots and soil microbes in $C N$ and $P$ dynamics in humid tropical forest ecosystem of Notrh east India, Doctoral Thesis, North Eastern Hill Univesity, Shilong.

Barbhuiya, A.R., A. Arunachalan, H.N. Pandey, M.L. Khan \& K. Arunachalan. 2012. Fine root dynamics in undisturbed and disturbed stands of a tropical wet evergreen forest in northeast India, Tropical Ecology 53(1): 69-79.

Bawa, K.S. \& S. Dayanandan. 1998. Climate change and tropical forest genetic resources. Climate Change 23: 449-466.

Black, C.A. 1968. Soil Plant Relations. J. Wiley \& Sons, New York.

Brassard, B.W., H.Y.H. Chen \& Y. Bergeron. 2009. Influence of environmental variability on root dynamics in northern forests. Crit. Rev. Plant Sci. 28: 179-197.

Brookes, P.C., A. Landman, G. Pruden \& G.S. Jenkinson. 1985. Chloroform fumigation and the release of soil nitrogen: A rapid direct extraction method to measure microbial biomass nitrogen in soil. Soil Biology \& Biochemistry 17: 837-842.

Chen, T.H., C.Y. Chiu, G.L. Tian. 2005. Seasonal dynamics of soil microbial biomass in coastal sand dune forest. Pedobiologia 49: 645-53

Gill, R.A. \& R.B. Jackson. 2000. Global patterns of root turnover for terrestrial ecosystems. New Phytol. 147: 13-32.

Jackon, R.B., H.A. Mooney \& E.D. Schulze. 1997. A global budget for fine root biomass, surface area, and nutrient contents. Proc. Nat. A.Scienc. 94: 7362-7366.

Jakson, M.L. 1958. Soil Chemical Analysis. Prentice Hall, Inc., Engle Wood Cliffs, New Jersey, 498p. 
Juwa, G.B. 1987. Soil and sites of selected plantation areas in the Kathmandu project area of the hill forestry development project. Kathmandu: Forest Research Division, Department of Forestry and Research, HMGN. 66p.

Kala, C.P. 2004. Studies on the Indigenous Knowledge, Practices and Traditional Uses of Forest Products by Human Societies in Uttaranchal State of India. Almora: GB Pant Institute of Himalayan Environment and Development.

Keyes, M.R. \& C.C. Grier. 1981. Above- and belowground net production in 40-year-old Douglas-fir stands on low and high productivity sites. Can. J. For. Res. 8: 265-279.

Mandal, T.N. 1999. Ecological analysis of recovery of landslide damaged sal forest ecosystem in Nepal Himalaya. Ph.D. Thesis, HindunUniversity, Varanasi, India.

Mandal, T.N. 2011. Seasonal variations in available $\mathrm{N}$ and $\mathrm{N}$ - mineralization in relation to fine roots in land slide damaged sites in the sal forest ecosystem of Nepal Himalaya. Neplease Journal of Biosciences 1: 114-124

Mc Grodly, M. \& W.L. Silver. 2000. Variations in Belowground Carbon storage and $\mathrm{Soil}_{2}$ Flux rates along a wet tropical Gradient. Bio-tropica 32(4a): 614-624.

Paudel, S. \& J.P. Shah. 2003. Physico-chemical characteristics of soil in tropical Sal (Shorea robusta Gaertn.) forests in eastern Nepal. Himalayan Journal of Science 1(2): 107-110.

Paul, E.A. \& F.E. Crark. 1989. Soil Biology and Biochemistry. Academic Press, Sandiego.

Piper, C.S. 1966. Soil and Plant Analysis. Hans Publisher, Bombay.

Semwal, D.P., P.L. Uniyal, Y.M. Bahuguna \& A.B. Bhatt. 2009. Soil nutrient storage under different forests types in a part of central Himalayas India. Annals of Forestry 17(1): 4352.

Sigdel, E.R. 1994. Physico-chemical properties of soil in Royal Chitwan National Park. M.Sc. Thesis, Central Department of Botany, Tribhuvan University. 49p

Singh, J.S., A.S. Raghubanshi, R.S. Singh \& S.C. Srivastava. 1989. Microbial Biomass acts as source of plant nutrients in dry tropical forest and savanna. Nature 338: 499-500.

Vance, E.D., P.C. Brookes \& D.S. Jenkinson. 1987. Microbial biomass measurement in forest soils: The use of the chloroform fumigation-incubation method in strongly acid soils. Soil Biology \& Biochemistry 19: 697-702.

Vogt, K.A., C.C. Grier \& D.J. Vogt. 1986. Production, turnover, and nutrientdynamics of aboveground and belowground detritus of world forests. Adv. Ecol. Res. 15: 303-377.

Walkley, A.E. \& J.A. Black. 1934. An examination of the Degtiga Vett. method for determining soil organic matter and proposed modification of the cromic acid titration method. Soil science 37(2):

Wang, C., S. Han, Y. Zhou, C. Yan, X. Cheng, X. Zheng \& M. Li. 2012. Responses of fine roots and soil $\mathrm{N}$ availability to short-term nitrogen fertilization in a broad-leaved Korean Pine mixed forest in northeastern China. PLoS One. 7(3) e31042. 